\title{
Oceanic hindcast simulations at high resolution suggest that the Atlantic MOC is bistable
}

\author{
J. Deshayes, ${ }^{1,2}$ A.-M. Tréguier, ${ }^{2}$ B. Barnier, ${ }^{3}$ A. Lecointre, ${ }^{4}$ J. Le Sommer, ${ }^{3}$ \\ J.-M. Molines, ${ }^{3}$ T. Penduff, ${ }^{3}$ R. Bourdallé-Badie, ${ }^{5}$ Y. Drillet, ${ }^{5}$ G. Garric, ${ }^{5}$ \\ R. Benshila, ${ }^{6}$ G. Madec, ${ }^{6}$ A. Biastoch, ${ }^{7}$ C. W. Böning, ${ }^{7}$ M. Scheinert, ${ }^{7}$ \\ A. C. Coward, ${ }^{8}$ and J. J.-M. Hirschi ${ }^{8}$
}

Received 29 April 2013; accepted 3 May 2013; published 19 June 2013.

[1] All climate models predict a freshening of the North Atlantic at high latitude that may induce an abrupt change of the Atlantic Meridional Overturning Circulation (hereafter AMOC) if it resides in the bistable regime, where both a strong and a weak state coexist. The latter remains uncertain as there is no consensus among observations and ocean reanalyses, where the AMOC is bistable, versus most climate models that reproduce a mono-stable strong AMOC. A series of four hindcast simulations of the global ocean at $1 / 12^{\circ}$ resolution, which is presently unique, are used to diagnose freshwater transport by the AMOC in the South Atlantic, an indicator of AMOC bistability. In all simulations, the AMOC resides in the bistable regime: it exports freshwater southward in the South Atlantic, implying a positive salt advection feedback that would act to amplify a decreasing trend in subarctic deep water formation as projected in climate scenarios. Citation: Deshayes, J., et al. (2013), Oceanic hindcast simulations at high resolution suggest that the Atlantic MOC is bistable, Geophys. Res. Lett., 40, 3069-3073, doi:10.1002/grl.50534.

\section{Introduction}

[2] Abrupt climate changes in the past 20,000 years are linked to switches of the AMOC [McManus et al., 2004]. When the AMOC is in the intense regime like at present, dense North Atlantic Deep Water (NADW) is formed at high latitude in spite of precipitations (that exceed evaporation), sea-ice melting, and river runoffs that all increase freshwater (hereafter FW) content, hence buoyancy of the upper ocean [Talley, 2008]. For very large FW forcing that impedes NADW formation, this AMOC regime is replaced by another regime, of much smaller intensity, driven by large-scale salinity contrasts [Rahmstorf, 1996]. The latter

\footnotetext{
Additional supporting information may be found in the online version of this article.

${ }^{1}$ LMI ICEMASA, University of Cape Town, South Africa.

${ }^{2}$ LPO, CNRS IRD IFREMER UBO IUEM, France.

${ }^{3}$ LGGE, CNRS UJF OSUG, France.

${ }^{4}$ LEGI, now at ISTerre, UJF CNRS UdS IRD IFSTTAR, France.

${ }^{5}$ MERCATOR Ocean, France.

${ }^{6}$ LOCEAN, CNRS IRD UPMC MNHN, France.

${ }^{7}$ GEOMAR Helmholtz-Zentrum für Ozeanforschung Kiel, Germany.

${ }^{8} \mathrm{NOC}$, Southampton, UK.
}

Corresponding author: J. DESHAYES, UCT Department of Oceanography, Rondebosch 7701, South Africa. (julie.deshayes@ird.fr)

(C)2013. American Geophysical Union. All Rights Reserved. 0094-8276/13/10.1002/grl.50534 regime transports less heat poleward than the intense regime; hence, it has been associated, in the past, with colder climate periods. Ocean-only models and climate models suggest that both $\mathrm{AMOC}$ regimes coexist for a specific range of $\mathrm{FW}$ forcing in the North Atlantic, the so-called bistable regime [Gregory et al., 2003; Dijkstra, 2007; Hawkins et al., 2011]. Actually, the existence of this regime is robust despite the remaining controversy on the physical mechanism providing the energy to sustain an overturning circulation, namely diapycnal mixing or wind divergence in the Southern Ocean [Kuhlbrodt et al., 2007; Fürst and Levermann, 2012]. FW transport by AMOC in the South Atlantic (hereafter $\mathrm{FT}_{\mathrm{ov}}$ ) is an indicator of the bistable regime [Rahmstorf, 1996; Dijkstra, 2007; Hawkins et al., 2011; Weijer et al., 2001; de Vries and Weber, 2005; Huisman et al., 2010]. Indeed, it directly gives the sign of AMOC salt-advection feedback: $\mathrm{FT}_{\mathrm{ov}}$ is positive when AMOC exports salinity to the south, in which case a small decrease in AMOC would export less salt, encouraging NADW formation and recovery of AMOC (negative feedback); on the other hand, $\mathrm{FT}_{\text {ov }}$ is negative when AMOC exports FW to the south, and a small decrease in AMOC would export less FW, reducing further NADW formation and AMOC (positive feedback) - a necessary condition for an abrupt change of the AMOC.

[3] There is a general consensus among predictions of future climate that FW forcing in the North Atlantic will increase, as precipitations increase and the Greenland ice sheet melts [Meehl et al., 2007]. As a consequence, most climate models predict a decrease of AMOC on decadal to multi-decadal timescales, with an amplitude that depends largely on the model [Schmittner et al., 2005], but none seems to predict an abrupt change of AMOC in the next century. Consistently, six out of eight climate models from the third phase of the Coupled Model Intercomparison Project (CMIP), constrained by present-day climate conditions, are in the mono-stable intense regime of AMOC-thus precluding a collapse [Drijfhout et al., 2011]. On the contrary, observational estimates [Saunders and King, 1995; Weijer et al., 1999; Bryden et al., 2011; Garzoli et al., 2012] and ocean reanalysis [Hawkins et al., 2011] suggest that presentday AMOC is in the bistable regime. As a result, climate models have been reported as "overly stable" [Hofmann and Rahmstorf, 2009], which substantially increased the uncertainty of future climate scenarios produced by these models. More recently, an intercomparison of climate models from the fifth phase of CMIP suggests that $40 \%$ of the models are in a bistable regime under historical and future climate scenarios [Weaver et al., 2012]. Hence, there remains 
DESHAYES ET AL.: SIMULATED AMOC FRESHWATER TRANSPORT

Table 1. Specificities of Model Simulations ${ }^{\mathrm{a}}$

\begin{tabular}{lcccccc}
\hline Simulations & A-HR & A-LR & B-HR & B-LR & C-HR & D-HR \\
\hline Hor. res. & $1 / 12^{\circ}$ & $1 / 4^{\circ}$ & $1 / 12^{\circ}$ & $1 / 4^{\circ}$ & $1 / 12^{\circ}$ & $1 / 12^{\circ}$ \\
Atm. forcing & \multicolumn{1}{c}{ ERAinterim } & a,b & \multicolumn{2}{c}{ ERAinterim ${ }^{\mathrm{a}}$} & CORE II & DFS4. $1^{\mathrm{d}}$ \\
Starting date & $01 / 01 / 89$ & $01 / 01 / 89$ & $01 / 10 / 99$ & $01 / 10 / 99$ & $01 / 01 / 78$ & $01 / 01 / 78$ \\
SSS restoring & $60^{\mathrm{e}, \mathrm{f}}$ & $60^{\mathrm{f}}$ & No & No & $36^{\mathrm{e}}$ & $300^{\mathrm{f}}$ \\
\hline
\end{tabular}

${ }^{\text {a }}$ Dee et al. [2011] with corrections of the large-scale shortwave flux bias toward Global Energy and Water Cycle Experiment (GEWEX) observations, ${ }^{\mathrm{b}}$ with correction of precipitations toward Global Precipitation Climatology Project (GPCP) data [Huffman et al., 2009], ' Large and Yeager [2009], ' Brodeau et al. [2010], ${ }^{\mathrm{e}}$ with $0.5 \mathrm{psu}$ limit, ${ }^{\mathrm{f}}$ with $4 \mathrm{~mm} /$ day limit. SSS restoring time scale given in days $/ 10 \mathrm{~m}$.

a large uncertainty in the likeliness of an abrupt change of present-day AMOC.

[4] The use of high-resolution ocean models to revisit the bistability issue of AMOC is, primarily, motivated by the fact that western boundary currents are properly resolved and substantially complicate the AMOC structure. In addition, non-eddy-resolving ocean models not only show underestimated interannual variability of the upper circulation (compared to estimates from altimetry, for example) but also exhibit substantial biases in their mean circulation, hydrography, and patterns of variability [Penduff et al., 2011]. For example, the main source of heat and salt to the surface branch of AMOC in the South Atlantic is provided by mesoscale eddy structures called Agulhas Rings. Explicitly modeling these features requires high horizontal resolution and has a significant impact on the AMOC variability [Biastoch et al., 2008]. Simulated $\mathrm{FT}_{\mathrm{ov}}$ has been reported to be sensitive to model resolution [Hawkins et al., 2011] as it depends on the northward salt transport by Agulhas Rings and, more generally, on the ocean circulation and hydrography in the South Atlantic. In this paper, we revisit estimates of $\mathrm{FT}_{\mathrm{ov}}$ under present-day conditions in a suite of global hindcast simulations at "eddy-resolving" $\left(1 / 12^{\circ}\right)$ resolution. An ensemble of global hindcast simulations, at such high resolution, is presently unique. Rather than attempting to explore the sensitivity of $\mathrm{FT}_{\mathrm{ov}}$ to individual settings of the simulations, we use the ensemble to demonstrate the robust behavior of $\mathrm{FT}_{\mathrm{ov}}$. We also compare results with companion lower resolution "eddy-permitting" $\left(1 / 4^{\circ}\right)$ simulations to clarify the impact of model resolution on simulated $\mathrm{FT}_{\mathrm{ov}}$.

\section{Model Experiments and Diagnostics}

[5] While $1 / 4^{\circ}$ global hindcast simulations produced by the DRAKKAR consortium have been widely studied and used to address scientific questions in physical oceanography, biogeochemistry, and marine biology (http://www.drakkar-ocean.eu); this paper introduces the first series of global $1 / 12^{\circ}$ ocean simulations developed by DRAKKAR. This ensemble of simulations, based on NEMO code (Nucleus for European Modelling of the Ocean), explores different model parameters and atmospheric forcings (detailed in Supplementary Information and Table S1) summarized in Table 1. High-resolution simulations (named -HR) have a nominal resolution of $1 / 12^{\circ}$, from 6 to $9.2 \mathrm{~km}$ in $50^{\circ} \mathrm{S}-50^{\circ} \mathrm{N}$, hence they can be considered as fully eddy-resolving there. Lower resolution simulations, with $1 / 4^{\circ}$ nominal resolution, are considered eddy-permitting. Simulations start from rest and climatological temperature and salinity (NODC_WOA98, Polar science center Hydrographic Climatology, and medatlas) except simulation A-HR that starts from C-HR in 1989. Atmospheric forcing fields, which combine atmospheric reanalyses with estimates from satellite observations, differ among simulations, but in all cases, surface heat fluxes are calculated from atmospheric conditions and upper ocean characteristics using bulk formulae. In all simulations but B-HR and B-LR, sea surface salinity (hereafter SSS) is restored to climatology with a time scale that depends on the simulation. Preliminary evaluation of the high-resolution simulations shows that they yield very similar global circulation, hydrography, and variability, which demonstrates the robustness of the model results at this resolution. This is clearly visible in the South Atlantic diagnostics that we present.

[6] The earliest part of simulations B-HR, B-LR, C-HR, and D-HR has not been analyzed because of initial adjustments (the time frame used in calculations is given in Table 2). Freshwater is referenced to 35.0 salinity. $\mathrm{FT}_{\text {tot }}$, the AMOC volume transport, and $\mathrm{FT}_{\mathrm{ov}}$ are calculated after removing from meridional velocities their contribution to the net volume transport across the section, as done in observations [Talley, 2008]. AMOC intensity and $\mathrm{FT}_{\mathrm{ov}}$ are integrated over the main cell of AMOC, i.e., from the surface down to the bottom of NADW branch, noted $z_{\mathrm{NADW}}$ (Table 2) as in Drijfhout et al. [2011] but contrary to Weaver et al. [2012] that integrate down to the bottom. As discussed

Table 2. Mean Simulated Circulation in Atlantic at $30^{\circ} \mathrm{S}^{\mathrm{a}}$

\begin{tabular}{lcccccc}
\hline Simulation & Time Frame & $\mathrm{FT}_{\text {tot }}$ & $\mathrm{FT}_{\text {ov }}$ & AMOC & $z_{\text {NADW }}$ & Depth of AMOC Max \\
\hline A-HR & $1989-2007$ & $195 \mathrm{mSv}$ & $-100 \mathrm{mSv}$ & $12.6 \mathrm{~Sv}$ & $2678 \mathrm{~m}$ & $1180 \mathrm{~m}$ \\
A-LR & $1989-2009$ & $234 \mathrm{mSv}$ & $-47 \mathrm{mSv}$ & $14.2 \mathrm{~Sv}$ & $3352 \mathrm{~m}$ & $1404 \mathrm{~m}$ \\
B-HR & $2002-2009$ & $157 \mathrm{mSv}$ & $-105 \mathrm{mSv}$ & $14.6 \mathrm{~Sv}$ & $2950 \mathrm{~m}$ & $1190 \mathrm{~m}$ \\
B-LR & $2002-2009$ & $298 \mathrm{mSv}$ & $-23 \mathrm{mSv}$ & $8.6 \mathrm{~Sv}$ & $2562 \mathrm{~m}$ & $1407 \mathrm{~m}$ \\
C-HR & $1994-2007$ & $207 \mathrm{mSv}$ & $-112 \mathrm{mSv}$ & $14.2 \mathrm{~Sv}$ & $2897 \mathrm{~m}$ & $1197 \mathrm{~m}$ \\
D-HR & $1989-2007$ & $221 \mathrm{mSv}$ & $-74 \mathrm{mSv}$ & $13.7 \mathrm{~Sv}$ & $2861 \mathrm{~m}$ & $1257 \mathrm{~m}$ \\
\hline
\end{tabular}

\footnotetext{
${ }^{\mathrm{a}} \mathrm{All}$ transports are defined positive northward. $\mathrm{FT}_{\mathrm{tot}}$ is the total freshwater transport across the section, after removing the contribution of the net volume transport; $\mathrm{FT}_{\mathrm{ov}}$ is the $\mathrm{AMOC}$ freshwater transport; AMOC is the intensity of the upper cell of the meridional overturning circulation, which carries NADW at depth. NADW branch extends from the depth of $\mathrm{AMOC}$ maximum to $z_{\mathrm{NADW}}$ (the depth where the meridional transport, cumulated from the surface downward, changes sign).
} 


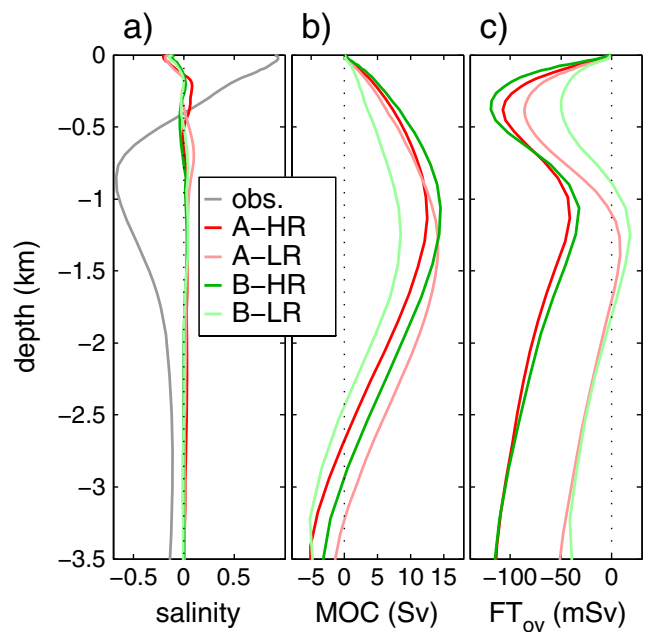

Figure 1. Mean vertical profiles in Atlantic at $30^{\circ} \mathrm{S}$. (a) Zonally-averaged observed salinity (minus the reference salinity $S_{0}=35.0$ ) and simulated anomalies, (b) meridional volume transport cumulated from surface to bottom, positive northward, and (c) overturning freshwater transport cumulated from surface to bottom.

in Drijfhout et al. [2011] and Sijp et al. [2012], it is important to exclude the contribution of the deep overturning cell associated with AABW. Equations are given in supplementary material. The depth of AMOC maximum locates the center of the main AMOC cell, as given by the depth of the vertical levels of the model (i.e., the currents, given at the model level depth, are not interpolated on the vertical). Simulations are diagnosed from the highest frequency outputs available (3 days for B-HR and B-LR, 5 days for A-HR, A-LR, and $\mathrm{D}-\mathrm{HR}$, and 1 month for C-HR, but the results are not sensitive to this choice). Note that calculations of $\mathrm{FT}_{\mathrm{ov}}$ based on time-averaged model outputs yield very similar mean values, suggesting that the correlation between velocity and salinity fluctuations hardly contributes to the temporal mean $\mathrm{FT}_{\text {ov }}$.

\section{Results}

[7] At $30^{\circ} \mathrm{S}$, across the South Atlantic subtropical gyre, the saltiest water masses are found in the upper ocean (from the surface down to $500 \mathrm{~m}$ approximately), above a minimum of salinity at about $1000 \mathrm{~m}$ depth, which corresponds to Antarctic Intermediate Waters (hereafter AAIW, gray line in Figure 1a and supplementary Figure S1). Below is NADW (between 2000 and $4000 \mathrm{~m}$ depth) and Antarctic Bottom Water (AABW). Simulated salinity profiles, averaged zonally across the section, are very close to observed climatology: anomalies are of the order of 0.1 (Figure 1a). The explicit representation of Agulhas Rings in eddy-resolving simulations (named -HR) enhances salinity variance at $400 \mathrm{~m}$ depth between $0^{\circ} \mathrm{E}$ and $15^{\circ} \mathrm{E}$, compared to lower resolution simulations (named -LR, supplementary Figure S1), but has a small impact on the zonally-averaged salinity profile.

[8] The upper ocean meridional currents mostly reflect the wind-driven gyre circulation: they are oriented northward in most of the basin, with maximum values in the eastern part of the section and strong southward velocities along the western boundary (supplementary Figure S1). At depth, the most visible coherent feature is the Deep Western Boundary Current that flows southward along the western boundary, while the other currents are weaker except on a few isolated spots near the bottom. Zonally integrating the meridional currents yields AMOC, with a northward branch from the surface down to $1000 \mathrm{~m}$ depth approximately, a southward branch that carries NADW (down to 2500-3200 m) and AABW (below), and a return AABW northward flow near the bottom (Figure 1b). Note that the maximum AMOC is deeper than the minimum salinity, hence, the upper branch of AMOC carries both salty subtropical water masses and fresher AAIW. While the intensity of simulated AMOC varies from $8.6 \mathrm{~Sv}$ to $14.6 \mathrm{~Sv}\left(1 \mathrm{~Sv}=10^{6} \mathrm{~m}^{3} \mathrm{~s}^{-1}\right)$ among all simulations, with no clear dependence on resolution, atmospheric forcing, or model parameters, the depth of the maximum AMOC is relatively robust among high-resolution simulations and markedly shallower than in low-resolution simulations (Figure $1 \mathrm{~b}$ and Table 2). The latter seems to originate from the western boundary current, which is intensified between 500 and $2000 \mathrm{~m}$ depth in high-resolution simulations (supplementary Figure S1). Recent observations of $\mathrm{AMOC}$ at $30^{\circ} \mathrm{S}$ suggest the AMOC is maximum at $1250 \mathrm{~m}$ depth [Garzoli et al., 2012], which is closer to the simulated value at high resolution than at low resolution. These observations also provide estimates of AMOC strength, that averages to $18.1 \mathrm{~Sv}$ from 2002 to 2011 , which is notably stronger than all simulations investigated here. This estimate is, nevertheless, based on several assumptions on the circulation at depth that was not directly measured.

[9] The vertical profile of the overturning FW transport (Figure 1c), cumulated from the surface downward, reveals that it changes direction twice. In the upper ocean, it is oriented southward because the circulation is oriented northward and subtropical water masses are saltier than the reference salinity $\left(S_{0}=35.0\right.$ as in previous studies [Hawkins et al., 2011; Huisman et al., 2010; Drijfhout et al., 2011] note that this choice has little impact on FW transports as we removed the net volume transport across the section, see Talley [2008] for a discussion on that topic). It changes direction as the upper branch of AMOC transports AAIW, which is fresher than $S_{0}$. Below, FW transport by the NADW branch is oriented southward, as NADW is fresher than $S_{0}$. Differences in the vertical profile of the overturning FW transport between high- and low-resolution simulations are dominated by differences in the circulation (this is verified by replacing the simulated salinity profiles by the observed one, which yields very similar FW transports). They are twofold: (i) FW southward transport in the upper ocean is larger in high-resolution simulations, and (ii) the upper branch of AMOC transports more AAIW northward in lowresolution simulations. The latter is due to the AMOC maximum being located deeper in low-resolution simulations. The former is due, in case of A-HR/LR, to the intensity of the upper ocean circulation $(0-500 \mathrm{~m})$ and, in case of B-HR/LR, to the intensity of AMOC which is $40 \%$ smaller in B-LR compared to B-HR. All three factors influence the AMOC upper branch partition into the "cold water route" (involving AAIW) and the "warm water route" (dominated by the Benguela current and Aghulas Rings), hence the overturning FW transport.

[10] Convergence of FW through the lateral boundaries of the Atlantic Ocean-Bering Strait and $30^{\circ} \mathrm{S}$ - compensate for the net evaporative surface fluxes (together with 
runoffs, basin-wide FW storage, and sea-ice FW fluxes). Observations suggest that FW transport through both boundaries is oriented toward the Atlantic Ocean and amounts to $215 \mathrm{mSv}$ across $30^{\circ} \mathrm{S}$ [Talley, 2008]. In our simulations, the total $\mathrm{FW}$ transport at $30^{\circ} \mathrm{S}$, noted $\mathrm{FT}_{\text {tot }}$, ranges from $157 \mathrm{mSv}$ to $298 \mathrm{mSv}$ (Table 2). Thus, observational estimates fall within the range of simulated average transports. One should not expect all simulations to have the same $\mathrm{FT}_{\text {tot }}$ for various reasons: (i) precipitation data sets are different (see Table 1), (ii) evaporation rates depend on simulated sea surface temperature hence are specific to each simulation, (iii) all simulations, except B-LR and B-HR, restore SSS to climatology with various time scales. Note, in particular, that $\mathrm{FT}_{\text {tot }}$ is higher in low- compared to high-resolution simulations.

[11] The overturning component of FW transport across $30^{\circ} \mathrm{S}$ (based on zonally-averaged velocity and salinity, see supplementary material for equations), noted $\mathrm{FT}_{\mathrm{ov}}$, also depends on the simulation: it ranges, on average, from -23 to $-112 \mathrm{mSv}$ (Table 2). It is, nevertheless, negative in all simulations, suggesting that present-day AMOC exports FW to the south. Besides, if we consider high-resolution simulations only, $\mathrm{FT}_{\mathrm{ov}}$ varies by less than $12 \%$ from the high-resolution ensemble average, which equals $-98 \mathrm{mSv}$. Hence, this estimate is robust despite differences in model characteristics and forcings. Finally, the two low-resolution simulations have $\mathrm{FT}_{\mathrm{ov}}$ smaller than the corresponding highresolution simulations (see Table 2 and Figure 1c). Differences in $\mathrm{FT}_{\mathrm{ov}}$ eventually reflect in $\mathrm{FT}_{\text {tot }}$, Bering Strait $\mathrm{FW}$ transport and surface FW fluxes [Drijfhout et al., 2011], or can be compensated for by the gyre contribution to $\mathrm{FT}_{\text {tot }}$ [Cimatoribus et al., 2012], but this goes beyond the scope of this paper.

[12] As the upper ocean salinity and circulation exhibit substantial seasonal fluctuations, we expect that $\mathrm{FT}_{\text {ov }}$ has some seasonal variability as well. Indeed, monthly averaged $\mathrm{FT}_{\text {ov }}$ in high-resolution simulations is minimum, at about $-200 \mathrm{mSv}$, in July, and maximum in February and October, at about $-10 \mathrm{mSv}$, and very similar among simulations (supplementary Figure S2). This amplitude of seasonal variations is larger than the high-resolution ensemble mean. We also observe substantial intra-seasonal variability in $\mathrm{FT}_{\mathrm{ov}}$ calculated from 5 days ( 3 days for B-HR) averages of the model outputs: values range from $-500 \mathrm{mSv}$ to $300 \mathrm{mSv}$. Most importantly, a substantial number of simulated values lie above 0, in September-November and January-March. We recommend that the intra-seasonal variability of $\mathrm{FT}_{\mathrm{ov}}$ is taken into account when interpreting estimates based on scattered observations. Note that a large part of this variability is related to changes in Ekman transport: in A-HR, the variance of $\mathrm{FT}_{\mathrm{ov}}$ anomalies from the mean seasonal cycle decreases by $70 \%$ when removing Ekman contribution (see Bryden et al. [2011] for a discussion on the contribution of Ekman transport to the overturning freshwater transport).

[13] The overturning component of $\mathrm{FW}$ transport at $30^{\circ} \mathrm{S}$ also exhibits variability on interannual time scales (supplementary Figure S3). Beside their differences in mean values (and despite a long-term drift in B-HR that uses uncorrected precipitations and no SSS restoring), highresolution simulations produce interannual fluctuations that are very similar: an increasing tendency from 1990 to 1998, local maxima in 1998, 2001, and 2004, and a decreasing tendency from 2004 to 2007. Low-resolution simulations have systematically larger $\mathrm{FT}_{\mathrm{ov}}$ than corresponding highresolution simulations, but exhibit coherent interannual fluctuations (and long-term drift in case of B-LR). This suggests that interannual fluctuations of $\mathrm{FT}_{\mathrm{ov}}$ are robust and do not significantly depend on the choice of atmospheric forcing nor model parameters.

\section{Conclusion}

[14] All four eddy-resolving simulations have an overturning FW transport negative on average, suggesting the present-day AMOC is in the bistable regime, a necessary condition for an abrupt change if $\mathrm{FW}$ forcing increases in the North Atlantic. It is remarkable that these models have very similar $\mathrm{FT}_{\mathrm{ov}}$ although they differ in model settings and large-scale circulation. In addition, they all exhibit substantial and consistent intra-seasonal to interannual variability in $\mathrm{FT}_{\mathrm{ov}}$. Hence, we claim that this result is robust. That present-day AMOC is bistable is consistent with observations [Saunders and King, 1995; Weijer et al., 1999; Bryden et al., 2011; Garzoli et al., 2012] and oceanic reanalyses [Hawkins et al., 2011] but contrasts with most climate models [Drijfhout et al., 2011; Weaver et al., 2012]. We suggest that model resolution via simulated $\mathrm{FT}_{\text {ov }}$, hence the AMOC upper branch partition into the cold and warm water routes, contributes to this particular bias of climate models, among other factors such as biases in evaporation and precipitation. This has already been suggested by Hawkins et al. [2011] but with opposite tendency: here, $\mathrm{FT}_{\mathrm{ov}}$ is larger in $1 / 4^{\circ} \mathrm{sim}-$ ulations compared to companion $1 / 12^{\circ}$ simulations. This tendency can be attributed to three factors: (1) intensity of the upper ocean circulation, (2) intensity of the AMOC, and (3) depth of AMOC maximum. The latter is confirmed by a 0.96 ensemble correlation between $\mathrm{FT}_{\text {ov }}$ and the depth of AMOC maximum in all six simulations, and is actually consistent with climate models [Drijfhout et al., 2011]. While the upper ocean circulation is expected to be more intense in any high-resolution simulation compared to lower resolution companion simulation, neither the intensity of the AMOC nor the depth of AMOC maximum can be linearly related to model resolution as both depend on multiple model parameters and forcings. This likely explains the discrepancy between our results and those of Hawkins et al. [2011].

[15] Ocean hindcast simulations often exhibit short-term (i.e., initial adjustment) and long-term drifts (as in B-LR and B-HR), which may have an impact on $\mathrm{FT}_{\mathrm{ov}}$ [Cimatoribus et al., 2012]. Diagnosis of a 300-year-long climatological $1 / 4^{\circ}$ ocean-only simulation [Penduff et al., 2011] shows that $\mathrm{FT}_{\mathrm{ov}}$ progressively changes from $-50 \mathrm{mSv}$ in the initial 30 years to $-75 \mathrm{mSv}$ in the final 30 years (the interannual standard deviation is $11 \mathrm{mSv}$ ). The depth of AMOC maximum in these two time periods is $1361 \mathrm{~m}$ and $1148 \mathrm{~m}$ respectively, which is consistent with the influence of the depth of AMOC maximum on $\mathrm{FT}_{\mathrm{ov}}$ described above. Hence, we conclude that ocean resolution has an impact on $\mathrm{FT}_{\mathrm{ov}}$ and that the latter is complex as it reflects the impact of ocean resolution on the intensity and depth of AMOC maximum. This suggests that increasing the resolution of the ocean component of climate models may affect the stability of AMOC and produce significantly different climate projections. Meanwhile, observing the hydrography and circulation in the South Atlantic, as planned by the South Atlantic Meridional Overturning Circulation (SAMOC) 


\section{DESHAYES ET AL.: SIMULATED AMOC FRESHWATER TRANSPORT}

group, should allow a thorough validation of FW transport and AMOC in ocean and climate models.

[16] Acknowledgments. This work is a contribution of the DRAKKAR project and Mercator-Ocean. Support to DRAKKAR comes from various grants and programs listed hereafter: CNES (OST/ST), CNRS INSU, GMMC; the German collaborative programs SFB754 at Kiel University funded by the Deutsche Forschungsgemeinschaft and Nordatlantik-II funded by BMBF (03F0605); the European Commission under Grant Agreement FP7-SPACE-2007-1-CT-218812-MYOCEAN. Mercator-Ocean is supported by French institutions (CNRS, IFREMER, IRD, Météo-France, and SHOM) and European programs (GMES and MyOcean). Computations were performed at French CINES (GENCI) on a SGI-altix computer, at Météo-France on a NEC-SX9, at NOCS on a CRAY-XE6, at Mercator-Ocean on a SGI-altix, and at DKRZ Hamburg on an IBM-Power6 system. All contributors to the DRAKKAR project are gratefully acknowledged.

[17] The Editor thanks two anonymous reviewers for their assistance in evaluating this paper.

\section{References}

Biastoch, A., J. R. E. Lutjeharms, C. W. Böning, and M. Scheinert (2008), Mesoscale perturbations control inter-ocean exchange south of Africa, Geophys. Res. Lett., 35, L20602, doi:10.1029/2008GL035132

Brodeau, L., B. Barnier, A. M. Treguier, T. Penduff, and S. Gulev (2010), An ERA40-based atmospheric forcing for global ocean circulation models, Ocean Model., 31, 88-104.

Bryden, H. L., B. A. King, and G. D. McCarthy (2011), South Atlantic overturning circulation at 24S, J. Mar. Res., 69, 39-56.

Cimatoribus, A. A., S. S. Drijfhout, M. Toom, and H. A. Dijkstra (2012), Sensitivity of the Atlantic meridional overturning circulation to South Atlantic freshwater anomalies, Clim. Dyn., 39, 2291-2306, doi:10.1007/s00382-012-1292-5.

Dee, D., et al. (2011), The ERA-Interim reanalysis: Configuration and performance of the data assimilation system, Quat. J. R. Meteorolog. Soc., 137, 553-597, doi:10.1002/qj.828.

Dijkstra, H. A. (2007), Characterization of the multiple equilibria regime in a global ocean model, Tellus, 59A, 695-705.

Drijfhout, S. S., S. L. Weber, and D. van der Swaluw (2011), The stability of the MOC as diagnosed from model projections for pre-industrial, present and future climates, Clim. Dyn., 37, 1575-1586, doi:10.1007/s00382010-0930-z.

Fürst, J. J., and A. Levermann (2012), A minimal model for wind- and mixing-driven overturning: Threshold behavior for both driving mechanisms, Clim. Dyn., 38, 239-260.

Garzoli, S. L., M. O. Baringer, S. Dong, R. C. Perez, and Q. Yao (2012), South Atlantic meridional fluxes, Deep Sea Res. I, 71, 21-32, doi:10.1016/j.dsr.2012.09.003.

Gregory, J. M., O. A. Saenko, and A. J. Weaver (2003), The role of the Atlantic freshwater balance in the hysteresis of the meridional overturning circulation, Clim. Dyn., 21, 707-717.

Hawkins, E., R. S. Smith, L. C. Allison, J. M. Gregory, T. J. Woollings, H. Pohlmann, and B. de Cuevas (2011), Bistability of the Atlantic overturning circulation in a global climate model and links to ocean freshwater transport, Geophys. Res. Lett., 38, L10605, doi:10.1029/2011GL047208.
Hofmann, M., and S. Rahmstorf (2009), On the stability of the Atlantic meridional overturning circulation, Proc. Natl. Acad. Sci., 106, 20572 20577., doi:10.1073/pnas.0909146106.

Huffman, G. J., R. F. Adler, D. T. Bolvin, and G. Gu (2009), Improving the global precipitation record: GPCP version 2.1, Geophys. Res. Lett., 36, L17808, doi:10.1029/2009GL040000.

Huisman, S. E., M. den Toom, H. A. Dijkstra, and S. Drijfhout (2010), An indicator of the multiple equilibria regime of the Atlantic meridional overturning circulation, J. Phys. Oceanogr., 40, 551-567, doi:10.1175/2009JPO4215.1.

Kuhlbrodt, T., A. Griesel, M. Montoya, A. Levermann, M. Hofmann, and S. Rahmstorf (2007), On the driving processes of the Atlantic meridional overturning circulation, Rev. Geophys., 45, RG2001, doi:10.1029/2004RG000166.

Large, W., and S. Yeager (2009), The global climatology of an interannually varying air-sea flux data set, Clim. Dyn., 33, 341-364, doi:10.1007/s00382-008-0441-3.

McManus, J. F., R. Francois, J.-M. Gherardi, L. D. Keigwin, and S. BrownLeger (2004), Collapse and rapid resumption of Atlantic meridional circulation linked to deglacial climate changes, Nature, 428, 834-837.

Meehl, G. A., et al. (2007), Global Climate Projections, in Climate Change (2007), The Physical Science Basis, Contribution of WG1 to the 4th Assessment Report of the IPCC, Cambridge University Press, Cambridge, UK, 996 p.

Penduff, T., M. Juza, B. Barnier, J. Zika, W. K. Dewar, A.-M. Treguier, J.-M. Molines, and N. Audiffren (2011), Sea level expression of intrinsic and forced ocean variabilities at interannual time scales, J. Clim., 24, 5652-5670, doi:10.1175/JCLI-D-11-00077.1.

Rahmstorf, S. (1996), On the freshwater forcing and transport of the Atlantic thermohaline circulation, Clim. Dyn., 12, 799-811.

Saunders, P. M., and B. A. King (1995), Oceanic fluxes on the WOCE A11 section, J. Phys. Oceanogr., 25, 1942-1958.

Schmittner, A., M. Latif, and B. Schneider (2005), Model projections of the North Atlantic thermohaline circulation for the $21 \mathrm{~s}$ century assessed by observations, Geophys. Res. Lett., 32, L23710, doi:10.1029/2005GL024368.

Sijp, W. P., M. H. England, and J. M. Gregory (2012), Precise calculations of the existence of multiple AMOC equilibria in coupled climate models. Part I: Equilibrium states, J. Clim., 25, 282-298, doi:10.1175/2011JCLI4245.1.

Talley, L. D. (2008), Freshwater transport estimates and the global overturning circulation: Shallow, deep and throughflow components, Prog Oceanogr., 78, 257-303.

de Vries, P., and S. L. Weber (2005), The Atlantic freshwater budget as a diagnostic for the existence of a stable shut down of the meridional overturning circulation, Geophys. Res. Lett., 32, L09606, doi:10.1029/2004GL021450.

Weaver, A. J., et al. (2012), Stability of the Atlantic meridional overturning circulation: A model intercomparison, Geophys. Res. Lett., 39, L20709, doi:10.1029/2012GL053763.

Weijer, W., W. P. M. de Ruijter, and H. A. Dijkstra (2001), Stability of the Atlantic overturning circulation: Competition between Bering Strait freshwater flux and Agulhas heat and salt sources, J. Phys. Oceanogr. $31,2385-2402$.

Weijer, W., W. P. M. de Ruijter, H. A. Dijkstra, and P. J. van Leeuwen (1999), Impact of interbasin exchange on the Atlantic overturning circulation, J. Phys. Oceanogr., 29, 2266-2284. 